\title{
Kolesterol, Asam Urat, dan Glukosa Darah Ayam Buras yang Diberi Pakan dengan Ramuan Herbal dan Ekstrak Kerang Bakau (Polymesoda erosa)
}

\author{
Takdir Saili*, Rahim Aka, Fuji Astuty Auza, Wa Laili Salido, Awal Maulid Sari \\ Fakultas Peternakan Universitas Halu Oleo, Kendari \\ Kampus Hijau Bumi Tridharma, Jl. H.E.A. Mokodompit, Anduonohu, Kendari 93232 \\ "Email korespondensi: takdir69@yahoo.com
}

(Diterima: 21-01-2019; disetujui 20-04-2019)

\begin{abstract}
ABSTRAK
Penelitian bertujuan untuk mengkaji pengaruh penambahan ramuan herbal yang dikombinasikan dengan ekstrak kerang bakau (Polymesoda erosa) di dalam pakan terhadap kadar kolesterol, asam urat dan glukosa darah ayam buras. Penelitian menggunakan 100 ekor ayam buras yang dipelihara mulai dari umur satu hari (DOC) sampai dengan umur 16 minggu. Penelitian menggunakan rancangan acak lengkap dengan 5 perlakuan dan 4 ulangan. Perlakuan terdiri atas R0 (pakan basal $+0 \%$ probiotik herbal $+0 \%$ ekstrak kerang bakau), $\mathrm{R} 1$ (pakan basal $+0,75 \%$ probiotik herbal $+1,5 \%$ ekstrak kerang bakau), R2 (pakan basal $+1,5 \%$ probiotik herbal $+3 \%$ ekstrak kerang bakau), R3 (pakan basal + $2,25 \%$ probiotik herbal $+4,5 \%$ ekstrak kerang bakau) dan R4 (pakan basal $+3 \%$ probiotik herbal + $6 \%$ ekstrak kerang bakau). Data yang diperoleh dari hasil penelitian dianalisis menggunakan sidik ragam dan dilanjutkan dengan uji jarak berganda Duncan. Hasil penelitian menunjukkan bahwa rataan

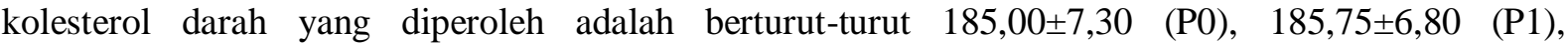
$153,25 \pm 19,06(\mathrm{P} 2), 167,75 \pm 17,72(\mathrm{P} 3), 214,00 \pm 19,18$ (P4). Rataan asam urat dalam darah yang

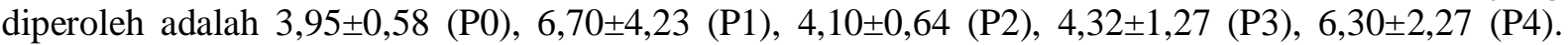
Sedangkan rataan glukosa darah yang diperoleh adalah $231 \pm 20,19(\mathrm{P} 0), 188,50 \pm 24,63(\mathrm{P} 1)$,

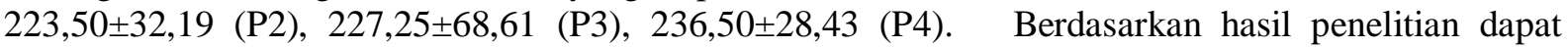
disimpulkan bahwa pemberian ramuan herbal dan ekstrak kerang bakau dalam pakan dapat mempengaruhi kadar kolestrol darah, namun tidak mempengaruhi kadar asam urat dan glukosa darah ayam buras. Kadar kolesterol darah terendah diperoleh pada perlakuan R2 dan R3 yang nyata berbeda dengan perlakuan R0, R1 dan R4.
\end{abstract}

Kata Kunci: ayam buras, ramuan herbal, kolesterol, asam urat, glukosa darah.

\section{ABSTRACT}

The objectives of this research was to evaluate the effect of agricultural by product-based feed supplemented with herbal concoction (HC) and mud clams extract (MC) on blood cholesterol, uric acid and blood glucose concentration. Completely randomized design was used with 4 treatments and 4 replications. Ninety day old chick of local village chicken was used in this experiment and kept up to 16 weeks during the experiment. The treatments consisted of basal feed (R0), basal feed $+0.75 \%$ $\mathrm{HC}+1.5 \% \mathrm{MC}(\mathrm{R} 1)$, basal feed $+1.5 \% \mathrm{HC}+3.0 \% \mathrm{MC}(\mathrm{R} 2)$, basal feed $+2.25 \% \mathrm{HC}+4.5 \% \mathrm{MC}$ (R3), basal feed $+3.0 \% \mathrm{HC}+6.0 \% \mathrm{MC}(\mathrm{R} 4)$. All data were analyzed using analysis of variance and different between treatments were proved using Duncan multiple range test. The results showed that the concentrations of blood cholesterol gained $(\mathrm{mg} / \mathrm{dl})$ were $185.00 \pm 7.30(\mathrm{P} 0), 185.75 \pm 6.80(\mathrm{P} 1)$, 153.25 $\pm 19.06(\mathrm{P} 2), 167.75 \pm 17.72(\mathrm{P} 3), 214.00 \pm 19.18(\mathrm{P} 4)$. The concentration of uric acid gained $(\mathrm{mg} / \mathrm{dl})$ were $3.95 \pm 0.58(\mathrm{P} 0), 6.70 \pm 4.23(\mathrm{P} 1), 4.10 \pm 0.64(\mathrm{P} 2), 4.32 \pm 1.27(\mathrm{P} 3), 6.30 \pm 2.27(\mathrm{P} 4)$. Whereas, the glucose concentration gained $(\mathrm{mg} / \mathrm{dl})$ were $231.00 \pm 20.19(\mathrm{P} 0), 188.50 \pm 24.63(\mathrm{P} 1)$, $223.50 \pm 32.19(\mathrm{P} 2), 227.25 \pm 68.61(\mathrm{P} 3), 236.50 \pm 28.43(\mathrm{P} 4)$. Based on variance analysis it was concluded that the treatments gave a significant effect $(\mathrm{P}<0.05)$ on blood cholesterol concentration, but had no effect $(\mathrm{P}>0.05)$ on uric acid and blood glucose concentration. Blood cholesterol concentrations were significant lower in treatment R2 and R3 compared to treatment R0, R1 and R4.

Keywords: blood glucose, cholesterol, herbal concoction, uric acid, village chicken 


\section{PENDAHULUAN}

Ayam buras adalah salah satu rumpun ayam lokal Indonesia yang tidak mempunyai ciri atau karakteristik khas dan tersebar di wilayah Indonesia (Nataamijaya 2010). Ayam buras dikenal sebagai ayam yang memiliki daya adaptasi baik di lingkungan marjinal, sehingga proses pemeliharaanyapun tergolong mudah.

Meningkatnya permintaan terhadap daging ayam buras atau ayam buras diikuti pula dengan peningkatan kebutuhan pakan yang turut dirasakan oleh peternak, sehingga beberapa perusahaan dan peternak mencari pakan alternatif untuk mengurangi biaya pakan yang tidak hanya memiliki kualitas yang baik, tetapi juga harga yang terjangkau. Pakan dikatakan berkualitas apabila memiliki kadar nutrien yang cukup, dapat memacu pertumbuhan, dan tidak menyebabkan penyakit bagi ternak yang mengonsumsinya. Oleh karena itu dalam proses pembuatan pakan biasanya dilakukan penambahan feed addittive untuk menunjang kualitas pakan, baik dari segi nutrisi, aroma dan palatabilitas pakan.

Penggunaan feed adittive sintetik terutama antibiotik sebagai pemacu pertumbuhan ternak telah dilarang, sehingga dibutuhkan alternatif lain sebagai penggantinya. Tanaman herbal merupakan tanaman obat yang berpotensi untuk dijadikan alternatif pengganti antibiotik karena mengandung zat bioaktif. Bahan-bahan ramuan herbal adalah media pengobatan yang menggunakan tanaman dengan kandungan bahan-bahan alamiah sebagai bahan bakunya (Agustina dan Purwanti, 2012). Penggunaan ramuan herbal memiliki efek samping negatif yang sangat kecil jika dibandingkan dengan obat-obat medis modern. Hal ini dikarenakan bahan baku ramuan herbal mengandung zat bioaktif yang sangat alami.

Selain penambahan feed adittif, pakan juga membutuhkan kandungan-kandungan nutrisi lain untuk memperbaiki proses pertumbuhan ternak, diantaranya adanya asamasam lemak yang tidak jenuh untuk proses pembentukan jaringan dan sel-sel pertumbuhan. Kerang bakau merupakan jenis moluska dalam kelas bivalvia yang banyak dijumpai di hutan mangrove dan memiliki kandungan nutrisi yang baik berupa asam lemak omega-3 yang merupakan asam lemak tidak jenuh yang kaya akan ikatan rangkap yakni mempunyai ikatan rangkap 3 dalam struktur molekulnya, yang mempunyai peranan positif pada kesehatan manusia yaitu antara lain: dapat menurunkan kadar kolesterol, membantu perkembangan syaraf pada bayi, menyembuhkan dan mencegah penyakit kardiovaskuler (Bruckner, 1986 dan Osman et al., 2001).

Aplikasi penggunaan ramuan herbal dan ekstrak kerang bakau (Polymesoda erosa) merupakan inovasi baru untuk menghasilkan pakan yang memiliki komposisi yang baik tanpa penggunaan feed aditif sintetik untuk memacu pertumbuhan. Salah satu kondisi yang dapat dilihat untuk keberhasilan metabolime nutrisi pada tubuh ternak adalah dengan melihat gambaran darah ternak. Gambaran darah yang normal akan menyebabkan metabolisme yang optimal sehingga akan menghasilkan capaian produksi yang baik. Penelitian ini dilakukan untuk melihat gambaran fisiologis darah ayam buras yang meliputi kadar kolesterol darah, asam urat dan glukosa darah.

\section{MATERI DAN METODE}

\section{Waktu dan lokasi penelitian}

Penelitian dilaksanakan selama 16 minggu di Laboratorium Teknologi dan Produksi Ternak Jurusan Peternakan Fakultas Peternakan Universitas Halu Oleo, Kendari.

\section{Metode Penelitian}

Materi yang digunakan dalam penelitian adalah 100 ekor day old chick (DOC) ayam buras tanpa membedakan jenis kelaminnya. Kandang yang digunakan yaitu kandang petak model panggung sebanyak 20 petak yang dilengkapi dengan tempat pakan dan air minum. Setiap petak kandang berukuran panjang $\mathrm{x}$ lebar x tinggi $(40 \mathrm{~cm}$ x $30 \mathrm{~cm}$ x $37 \mathrm{~cm}$ ). Pada setiap kandang diisi lima ekor ayam percobaan.

\section{Metode Penelitian}

Rancangan percobaan yang digunakan adalah Rancangan Acak Lengkap (RAL) dengan lima perlakuan dan empat ulangan. Perlakuan terdiri atas pakan basal $+0 \%$ ramuan herbal $+0 \%$ ekstrak kerang bakau (R0), pakan basal $+0,75 \%$ ramuan herbal $+1,5 \%$ ekstrak kerang bakau (R1), pakan basal $+1,5 \%$ ramuan herbal $+3 \%$ ekstrak kerang bakau (R2), pakan basal $+2,25 \%$ ramuan herbal $+4,5 \%$ ekstrak kerang bakau (R3), dan pakan basal $+3 \%$ ramuan herbal $+6 \%$ ekstrak kerang bakau (R4). Komposisi bahan pakan disajikan pada Tabel 1. 
Tabel 1. Komposisi bahan pakan dan kandungan nutrien pakan penelitian

\begin{tabular}{lllllll}
\hline \hline Bahan pakan & $\%$ & $\begin{array}{l}\text { KA } \\
(\%)\end{array}$ & $\begin{array}{c}\text { PK } \\
(\%)\end{array}$ & $\begin{array}{c}\text { LK } \\
(\%)\end{array}$ & $\begin{array}{c}\text { SK } \\
(\%)\end{array}$ & $\begin{array}{l}\text { Abu } \\
(\%)\end{array}$ \\
\hline Jagung kuning & 43 & 6,54 & 4,08 & 1,74 & 0,40 & 0,85 \\
Dedak halus & 32 & 4,23 & 3,81 & 2,92 & 2,30 & 1,80 \\
Tepung ikan & 25 & 3,42 & 12,15 & 0,64 & 0,04 & 5,8 \\
\hline Pakan komplit & 100 & 14,20 & 20,04 & 5,31 & 2,75 & 8,45 \\
\hline
\end{tabular}

Keterangan $: \mathrm{KA}=$ Kadar Air, PK = Protein Kasar, LK = Lemak Kasar, SK = Serat Kasar

Sebelum perlakuan pada hewan uji, ayam buras dipuasakan terlebih dahulu selama 16 jam untuk menstabilkan kadar kolesterol, asam urat, dan glukosa darah dari pengaruh pemberian pakan. Selama pemuasaan, ternak tetap diberikan air minum. Pengukuran Kadar kolesterol darah, asam urat dan glukosa darah dihitung dengan menggunakan NESCO MultiCheck.

\section{Variabel Penelitian}

Analisis Kadar Kolesterol; Kadar kolesterol darah diukur dengan menggunakan alat NESCO MultiCheck. Sebelum digunakan, NESCO MultiCheck dinyalakan dengan menekan tombol "on", kemudian dipasangi chip kolesterol dan strip kolesterol kedalam alat NESCO MultiCheck. Darah diambil melalui Vena brachialis dibagian sayap, kemudian diteteskan pada NESCO MultiCheck. Dalam waktu 150 detik kadar kolesterol darah akan terukur secara otomatis dan hasilnya dapat dibaca pada monitor NESCO MultiCheck.

Analisis Asam Urat; Mengeluarkan chip dan strip kolesterol yang ada pada alat NESCO MultiCheck, lalu menggantinya dengan chip asam urat dan meneteskan darah pada strip asam urat kemudian memasangnya pada chip asam urat dan dalam waktu 20 detik kadar asam urat akan terbaca pada monitor NESCO MultiCheck.

Glukosa Darah; Mengeluarkan chip dan strip asam urat yang ada pada alat NESCO MultiCheck, lalu menggantinya dengan chip glukosa dan meneteskan darah pada strip glukosa kemudian memasangnya pada chip glukosa dan dalam waktu 10 detik kadar glukosa darah secara otomatis akan terbaca pada monitor NESCO MultiCheck.

\section{Analisis Data}

Data yang diperoleh diolah dengan menggunakan sidik ragam sesuai Rancangan Acak Lengkap (RAL) dan apabila perlakuan berpengaruh nyata diuji lanjut dengan menggunakan Uji Wilayah Berganda Duncan (Gasperz, 1994).

\section{HASIL DAN PEMBAHASAN}

Rataan kolesterol darah, asam urat dan glukosa darah ayam buras untuk masing-masing perlakuan disajikan pada Tabel 2. Hasil perhitungan sidik ragam menunjukkan bahwa penambahan ramuan herbal dan ekstrak kerang bakau dengan level berbeda berpengaruh nyata $(\mathrm{P}<0,05)$ terhadap kolesterol darah ayam buras, namun tidak berbeda $(\mathrm{P}>0,05)$ terhadap kadar asam urat dan glukosa darah ayam buras.

Tabel 2. Rataan kolesterol darah, asam urat dan glukosa darah (mg/dl) ayam buras umur 16 minggu

\begin{tabular}{|c|c|c|c|c|c|}
\hline \multirow{2}{*}{ Parameter } & \multicolumn{5}{|c|}{ Perlakuan } \\
\hline & R0 & $\mathrm{R} 1$ & $\mathrm{R} 2$ & R3 & $\mathrm{R} 4$ \\
\hline $\begin{array}{l}\text { Kolesterol Darah } \\
(\mathrm{mg} / \mathrm{dl})\end{array}$ & $185,00 \pm 7,30^{\mathrm{b}}$ & $185,75 \pm 6,80^{b}$ & $153,25 \pm 19,06^{\mathrm{c}}$ & $167,75 \pm 17,72^{\mathrm{bc}}$ & $214,00 \pm 1,30^{\mathrm{a}}$ \\
\hline $\begin{array}{l}\text { Asam Urat } \\
(\mathrm{mg} / \mathrm{dl})\end{array}$ & $3,95 \pm 0,58$ & $6,70 \pm 4,23$ & $4,10 \pm 0,64$ & $4,32 \pm 1,27$ & $6,30 \pm 2,27$ \\
\hline $\begin{array}{l}\text { Glukosa Darah } \\
(\mathrm{mg} / \mathrm{dl})\end{array}$ & $231,00 \pm 20,19$ & $188,50 \pm 24,63$ & $223,50 \pm 32,19$ & $227,25 \pm 68,61$ & $236,50 \pm 28,43$ \\
\hline
\end{tabular}




\section{Kolesterol Darah}

Hasil analisis ragam menunjukkan bahwa penambahan berbagai level ramuan herbal dan ekstrak kerang bakau (Polymesoda erosa) di dalam pakan ayam buras berpengaruh nyata $(\mathrm{P}<0,05)$ terhadap kadar kolesterol darah. Kolesterol darah pada perlakuan R2 dan R3 nyata $(\mathrm{P}<0,05)$ lebih rendah dibandingkan dengan perlakuan $\mathrm{R} 0$ dan $\mathrm{R} 1$, dan $\mathrm{R} 4$. Hal ini diduga karena adanya perbedaan level pemberian ramuan herbal dan ekstrak kerang bakau pada setiap perlakuan, dimana pada level R1 $(0,75 \%$ ramuan herbal $+1,5 \%$ ekstrak kerang bakau) belum mampu menurunkan kadar kolesterol darah secara signifikan, tetapi pada R2 $(1,5 \%$ ramuan herbal $+3 \%$ ekstrak kerang bakau) dan R3 (2,25\% ramuan herbal + 4,5\% ekstrak kerang bakau) dapat menurunkan kadar kolesterol ayam buras. Hal ini sesuai dengan hasil penelitian (Agustina, 2006) yang menyatakan bahwa penggunaan ramuan herbal sebanyak 2,5 ml/liter air minum dapat menurunkan kadar kolesterol darah pada ayam. Pada perlakuan R4 (3\% ramuan herbal $+6 \%$ ekstrak kerang bakau) menunjukkan kenaikan kadar kolesterol darah pada ayam buras yang cukup signifikan diantara perlakuan yang lain. Perbedaan ini diduga karena persentase kadar pemberian ramuan herbal dan ekstrak kerang bakau yang menimbulkan gangguan terhadap proses metabolisme di dalam tubuh ayam buras. Sebagaimana hasil penelitian (Agustina dan Purwanti, 2012) yang menyatakan bahwa penggunaan feed additive ramuan herbal dalam pakan dan dosis yang digunakan harus tepat karena bila tidak, dapat menyebabkan terjadinya toksik yang akan merusak jaringan organ dalam terutama organ hati yang merupakan pusat metabolisme.

Hasil uji polinomial antar perlakuan R0 $(185,00 \pm 7,30), \quad \mathrm{R} 1 \quad(185,75 \pm 6,80), \quad \mathrm{R} 2$ $(153,25 \pm 19,06), \quad R 3(167,75 \pm 17,72)$ dan R4 $(214,00 \pm 1,30)$ menunjukkan pola yang bersifat kuadratik, dimana pada level terendah (R1) tidak memberikan respon dan pengaruh yang signifikan terhadap kolesterol ayam buras atau sama dengan R0. Namun pada R2 dan R3, kolesterol darah mengalami penurunan dan mengalami kenaikan kembali pada level R4.

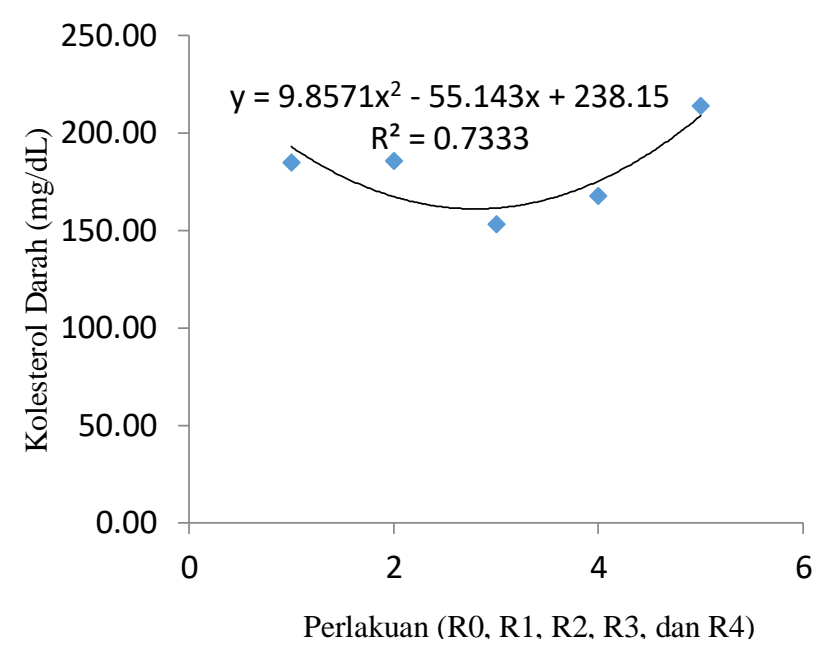

Gambar 1. Grafik kolesterol darah ayam buras pada berbagai level perlakuan

Rataan yang menunjukkan perbedaan yang nyata $(\mathrm{P}<0,05)$ terhadap kadar kolesterol darah ayam buras mungkin disebabkan oleh kandungan ramuan herbal yang memiliki zat bioaktif seperti kurkumin sebagai anti oksidan dan ekstrak kerang bakau yang memiliki zat aktif dan kandungan asam lemak tidak jenuh yang dapat membantu menurunkan kadar kolesterol di dalam darah ayam. (Agustina dan Purwanti, 2012) menyatakan bahwa ramuan herbal serbuk maupun cair mempunyai kandungan zat bioaktif yaitu kurkumin sebagai antioksidan yang mampu mencegah pembentukan kolesterol. Ditambahkan Candra (2011), bahwa flavonoid dan eugenol berperan sebagai antioksidan, yang dapat menetralkan radikal bebas, menetralkan kolesterol dan bersifat antikanker. Selain itu (Bruckner, 1986 dan Osman et al.,2001) menyatakan bahwa kerang bakau Polymesoda erosa memiliki kandungan nutrisi yang baik berupa asam lemak omega-3 yang merupakan asam lemak tidak jenuh yang kaya akan ikatan rangkap yakni mempunyai ikatan rangkap 3 dalam struktur molekulnya, yang mempunyai peranan positip pada kesehatan manusia yaitu antara lain: dapat menurunkan kadar kolesterol, membantu perkembangan syaraf pada bayi, menyembuhkan dan mencegah penyakit kardiovaskuler.

Data pada Tabel 2 menunjukan bahwa kadar kolesterol darah ayam buras berkisar antara 153,25 mg/dl sampai 214,00 mg/dl. Hasil penelitian di atas sama dengan hasil penelitian Mangisah (2003) yang menyatakan bahwa kadar kolesterol ayam broiler berkisar antara $125-200 \mathrm{mg} / \mathrm{dl}$. Kadar kolesterol dalam darah dianggap aman jika tidak melebihi $225 \mathrm{mg} / \mathrm{dl}$ 
(Pilliang dan Djojosoebagyo 1990). Kolestrol adalah termasuk keluarga lemak yang disimpan dalam jaringan hati atau dinding pembuluh darah. Kolesterol berhubungan erat dengan keadaan aterosklerosis, dimana terdapat penimbunan bahan-bahan mengandung kolesterol pada dinding pembuluh darah yang menyebabkan penyakit jantung (Tillman et al., 1998).

\section{Asam Urat}

Asam urat merupakan hasil metabolisme normal dari pencernaan protein atau dari penguraian senyawa purin yang seharusnya akan dibuang melalui ginjal, feses, atau keringat (Sustrani et al., 2004). Rataan kadar asam urat ayam buras yang ditampilkan pada Tabel 2 tidak berbeda antar perlakuan $(\mathrm{P}>0,05)$. Hal ini menunjukkan bahwa ramuan herbal dan ekstrak kerang bakau (Polymesoda erosa) kurang berperan aktif terhadap proses metabolisme nutrisi khususnya metabolisme protein di dalam tubuh, karena kedua komponen tersebut lebih berperan aktif terhadap sistem imun, palatabilitas pakan dan memperbaiki sistem penyerapan nutrisi pada saluran pencernaan. Hal ini sesuai dengan pendapat (Agustina, 2006) yang menyatakan bahwa penggunaan ramuan herbal pada ayam dapat memperbaiki konsumsi pakan, konversi pakan, menurunkan kadar kolesterol darah, serta menekan mortalitas. Hal senada juga dikemukakan oleh Bruckner (1986) dan Osman et al. (2001) bahwa kerang bakau memiliki kandungan nutrisi yang baik berupa asam lemak omega-3 yang merupakan asam lemak tidak jenuh yang kaya akan ikatan rangkap (ikatan rangkap 3) dalam struktur molekulnya yang mempunyai peranan positif pada kesehatan.

Dilihat dari kisarannya, konsentrasi asam urat yang diperoleh pada penelitian ini berkisar antara 3,95-6,70 mg/dl. Hasil ini sama dengan yang dilaporkan oleh El-Katcha et al. (2014) yang mendapatkan kisaran asam urat pada ayam sekitar 4,87-6,57 $\mathrm{mg} / \mathrm{dl}$ dan masih termasuk dalam kategori normal. Unggas berbeda dengan mamalia karena pada mamalia indikator metabolisme protein dapat dilihat dari kadar urea dalam darah, sedangkan pada unggas produk akhir utama metabolisme protein berupa asam urat (Golstein dan Skadhauge, 2000), karena unggas tidak mampu menghasilkan arginase, enzim yang berperan dalam siklus urea. Asam urat secara normal diproduksi hati yang merupakan hasil dari metabolisme nitrogen atau protein dan akan diekresikan keluar tubuh dalam bentuk urin dengan bantuan ginjal. Asam urat sendiri tidak beracun atau berbahaya dalam tubuh ayam, akan tetapi jika membentuk kristal urat akan merusak jaringan tubuh, ini terjadi akibat tidak segera diekresikan ke luar tubuh yang dikarenakan adanya gangguan ginjal (Sulistyoningsih dan Rakmawati, 2015).

\section{Glukosa Darah}

Berdasarkan hasil analisis ragam diketahui bahwa penambahan ramuan herbal dan ekstrak kerang bakau (Polymesoda erosa) dengan berbagai tingkat yang berbeda, tidak berpengaruh nyata $(\mathrm{P}>0,05)$ terhadap kadar glukosa darah ayam buras. Kadar glukosa darah pada setiap perlakuan relatif sama. Hal tersebut diduga bahwa kadar glukosa darah cenderung dipertahankan dalam kisaran normal. Glukosa darah diatur agar selalu dipertahankan pada kondisi normal (sehat) dalam tubuh melalui proses homeostasis dengan bantuan hormon insulin yang disekresikan oleh kelenjar pankreas (Adisuworjo et al., 2001).

Rataan glukosa darah ayam buras pada setiap perlakuan, masih dalam batasan yang normal $(188,50-236,50 \mathrm{mg} / \mathrm{dl})$. Hazelwood (1986) menyatakan bahwa kadar glukosa darah yang normal pada ayam berkisar antara 180$250 \mathrm{mg} / \mathrm{dl}$. Sedangkan Scanes et al. (2004) melaporkan bahwa kadar glukosa darah ayam ras memiliki variasi sekitar 156 sampai 330 $\mathrm{mg} / \mathrm{dl}$. Kadar glukosa darah ayam yang normal mungkin disebabkan oleh sifat agresif, lincah dan kuat yang memiliki ayam buras (Partasasmita et al, 2016), sehingga glukosa yang berada dalam peredaran darah langsung terpakai untuk menghasilkan energinya. Lebih jauh hal tersebut menunjukkan bahwa energi yang berada di dalam ransum termanfaatkan dengan baik oleh tubuh ayam buras. Sejalan dengan tujuan penelitian, pemberian ramuan herbal dan ekstrak kerang bakau (Polymesoda erosa) di dalam ransum dengan berbagai level yang berbeda diharapkan dapat meningkatkan efisiensi penggunaan pakan untuk pertumbuhan dan hidup pokok ayam buras.

Ransum yang tidak efisien penggunaannya, ditunjukkan oleh kadar glukosa darah di atas normal pada ayam buras. Kadar glukosa darah melebihi angka normal, dapat menimbulkan kerusakan pada jaringan karena dehidrasi dan kehilangan ion-ion penting serta 
akan mempercepat proses penuaan protein (Colby, 1985). Ganong (2012) menyatakan bahwa variasi kadar glukosa dalam darah disebabkan oleh beberapa faktor yaitu umur, aktivitas fisik, jenis kelamin, dan efisiensi pemanfaatan energi dan protein di dalam tubuh.

Seiring bertambahnya umur ayam buras, maka organ tubuh mengalami penurunan fungsinya termasuk sel beta pada pankreas yang memproduksi insulin. Fungsi sel beta pankreas mengalami penurunan bergantung pada beban kerja sel beta pankreas yang dipengaruhi oleh tingkat resistensi insulin (Holt, 2009). Tekanan stres akan mempengaruhi produksi glukosa dalam darah. Hal tersebut dikarenakan hormon adrenalin sebagai pengatur gula darah akan tidak stabil, sehingga mengakibatkan hormon insulin kesulitan untuk menstabilkan gula darah. Dalam keadaan tekanan stres, mekanisme glukoneogenesis juga akan meningkat untuk memenuhi keperluan energi (Mushawwir et al, 2011). Aktivitas fisik ayam buras yang aktif dan lincah, diduga mempengaruhi penggunaan glukosa darah. Glukosa darah ini lebih cepat ditransformasikan sebagai energi. Variasi kadar glukosa disetiap ulangan diduga dipengaruhi oleh jenis kelamin ayam buras yang diteliti. Umumnya jantan mempunyai kecepatan pertumbuhan dan aktivitas hidupnya lebih tinggi dibandingkan betina, oleh karena itu glukosa darah pada ayam jantan akan lebih banyak ditransformasikan untuk keperluan energinya, sehingga kadar glukosa ayam jantan akan lebih rendah dibandingkan dengan ayam betina.

\section{KESIMPULAN}

Berdasarkan hasil pembahasan dapat disimpulkan bahwa pemberian kombinasi 1,5\% ramuan herbal $+3,0 \%$ ekstrak kerang bakau pada $\mathrm{R} 2$ dan $2,25 \%$ ramuan herbal $+4,5 \%$ ekstrak kerang bakau pada R3 mampu menurunkan kadar kolesterol darah pada ayam buras, tetapi kolesterol darah meningkat kembali dengan pemberian 3,0\% ramuan herbal $+6,0 \%$ ekstrak kerang bakau pada R4. Perlakuaan tidak memberikan pengaruh nyata terhadap kadar asam urat dan glukosa darah, namun cenderung untuk tetap mempertahankan dalam kisaran normal.

Sebaiknya pemberian ramuan herbal dan ekstrak kerang bakau pada ayam buras tidak melebihi dosis yang ditentukan, karena dapat menyebabkan gangguan kesehatan pada ternak.

\section{DAFTAR PUSTAKA}

Adisuwirjo, D., Sutrisno, \& S.J.A. Setyawati. 2001. Dasar Fisiologi Ternak. Fakultas Peternakan. Universitas Jenderal Soedirman. Purwokerto.

Agustina, L. 2006. Penggunanan Ramuan Herbal Sebagai Feed Additive Untuk Meningkatkan Performans Broiler. Prosiding Lokakarya Nasional Inovasi Teknologi dalam Mendukung Usaha Ternak Unggas Berdaya Saing. Pusat Penelitian dan Pengembangan Peternakan. Bogor.

Agustina, L. \& S. Purwanti. 2012. Ilmu Nutrisi Ternak Unggas. Rumah Pengetahuan. Solo.

Bruckner, G. 1986. Fats, their positional isomer, and platelete function. Journal of Medical Technology 3 (1):24-27.

Candra. 2011. Kemangi Menjaga Kesehatan Reproduksi. http://www.tribunnews. Com/2011/09/28/kemangi-menjagakesehatan-reproduksi. (11 Desember 2011).

Colby, D. 1985. Biochemistry: A Synopsis. Diterjemahkan oleh : Dharma, Adjie. 1996. Ringkasan biokimia harper. Penerbit buku kedokteran EGC. Jakarta.

El-Katcha, M.I., M.A. Soltan, H.F. El-Kaney, \& R.K. El-Sayed. 2014. Growth performance, blood parameters, immune response and carcass traits of broiler chicks fed on graded levels of wheat instead of corn without or with enzyme supplementation. Alexandria Journal of Veterinary Sciences 40:95-111.

Ganong. 2012. Buku Ajar Fisiologi Olahraga, Edisi 22. EGC. Jakarta. HIm 290-230.

Gaspersz, V. 1994. Metode Rancangan Percobaan untuk Ilmu-ilmu Pertanian, Teknik dan Biologi. Buku. CV Armico. Bandung.

Golstein, D. \& E. Skadhauge. 2000. Renal and Excretion Regulation of Body Fluid Composition. dalam : Wittow, G.C. (Ed). Sturkie's Avian Physiology. $5^{\text {th }}$ Ed. Academic Press. San Diego. pp. 265-297.

Hazelwood, R.L. 1986. Carbohydrate Metabolism. In Avian Physiology. Editor 
P.D. Sturkie. Springer. New York. pp 303-325.

Holt, P. 2009. A Practice Approach for Healtcare Professionals. John Wiley\& Sons, Ltd. United Kingdom.

Mangisah, I. 2003. Pemanfaatan Kunyit dan Temulawak Sebagai Upaya Menurunkan Kadar Kolesterol Broiler. Fakultas Peternakan Universitas Diponegoro. Semarang.

Mushawwir, A., \& D. Latipudin. 2011. Beberapa Parameter Biokimia Darah Ayam Ras Petelur Fase Grower dan Layer dalam Lingkungan "Upper Zonathermoneutral". Jurnal Peternakan Indonesia 13(3):191-198.

Nataamijaya, A.G. 2010. Pengembangan potensi ayam lokal untuk menunjang peningkatan kesejahteraan petani. Jurnal Litbang Pertanian 29(4):131-138.

Osman, H., AR. Suriah, \& EC. Law. 2001. Fatty Acid Composition and Cholesterol Contens of Selected Marine Fish in Malaysian Waters. Food Chemistry 73:55-60

Partasasmita, R., A.R. Hidayat, S.T. Erawan, \& J. Iskandar. 2016. Pengetahuan lokal masyarakat Desa Karangwangi, Kabupaten Cianjur tentang variasi (ras), pemeliharaan, dan konservasi ayam (Gallus gallus domesticus Linnaeus, 1758). Prossiding Seminar Nasional Masyaraat Biodiversity Indonesia 2(1):113-119.

Piliang, WG. \& S. Djojosoebagio. 1990. Fisiologi Nutrisi Vol I. Departemen Pendidikan dan Kebudayaan. Direktorat Jenderal Pendidikan Tinggi. Pusat Antar Universitas Ilmu Hayati. Institut Pertanian Bogor.

Scanes, G.C., G. Brant, \& M.E. Esminger. 2004. Poultry Science, 4th ed. Pearson Prentice Hall. New Jersey.

Sulistyoningsih, M. \& R. Rakmawati. 2015. Optimalisasi Feed Additive Herbal dengan Intermittent Lighting untuk Menurunkan Asam Urat dan Kolesterol Pada Ayam Broiler. Seminar Nasional Pangan Lokal, Bisnis dan Eko-Industri. Semarang 1 Agustus 2015.
Sustrani, L., A. Syamsir A, \& H. Iwan. 2004. Asam Urat Informasi Lengkap untuk Penderita dan Keluarga. Eedisi 6. Gramedia. Jakarta.

Tillman, A.D., H. Hartadi, S. Reksohadiprodjo, S. Prawirokusumo, \& S. Lebdosoekojo. 1998. Ilmu Makanan Ternak Dasar. Gajah Mada University Press. Yogyakarta. 